\title{
KURIKULUM U FUNKCIJI KVALITETNOG OSNOVNOG OBRAZOVANJA - OTVARANJE PROSTORA ZA AUTONOMIJU ŠKOLA
}

\author{
dr Vlasta Sučević \\ VŠSS za vaspitače, Kruševac \\ e-mail: vsucevic@vaspks.edu.rs \\ dr Marija D.Sakač \\ Pedagoški fakultet, Sombor \\ e-mail: umo@eunet.rs \\ dr Anđelka Bulatović, prof \\ VŠSS za vaspitače, Novi Sad \\ e-mail: dragibulatovic@yahoo.it
}

\begin{abstract}
Rezime
Kvalitet u svetu smatra se najznačajnijim fenomenom našeg doba, sa stalnim trendom njegovog poboljšanja. Reč je o novoj filozofiji življenja. Vreme koje je pred nama, posmatrajući sa aspekta obrazovanja, sve više karakteriše porast potreba za što kvalitetnijim znanjem. Reformski pokret strukture novog kurikuluma donosi važne promene posebno u shvatanju važnosti kurikuluma. Proces kreiranja kurikuluma akcent pomera sa teorijskog modelovanja na plan prakse i konteksta - društvena zajednica, škola, razred, porodica. Reformska promena sa klasičnih nastavnih planova i programa na kurikulum predstavlja premeštanje težišta obrazovnog procesa sa sadržaja na ciljeve i ishode obrazovanja, te razvoj sistema evaluacije i samoevaluacije u obrazovanju i zasnivanje obrazovnih sadržaja na obrazovnim oblastima. Predmet ovog rada je sagledavanje nove strukture kurikuluma u koncept evropskog kvalitetnog obrazovanja. Osnovni korak u prelasku kurikuralnog koncepta obrazovanja zasnovanog na ishodima podrazumeva definisanje ishoda obrazovanja za znanja, umenja, stavove i vrednosti koje učenici treba da poseduju nakon završstka određenog nivoa obrazovanja. U radu se razmatra teorijski koncept reformske promene kurikuluma i odnos nacionalnog i školskog kurikuluma, te nova struktura školskog kurikuluma. Cilj rada je da predstavi koncept obrazovanja usmerenog na ishode i otvaranje prostora za autonomiju škola i nastavnika.
\end{abstract}

Ključne reči: struktura kurikuluma/ kvalitet obrazovanja/ školski kurikulum/ ishodi obrazovanja/ autonomija škola i nastavnika

\section{Uvodna razmatranja}

Kvalitet u svetu smatra se najznačajnijim fenomenom našeg doba, sa stalnim trendom njegovog poboljšanja. Reč je o novoj filozofiji življenja. Vreme koje je pred nama, posmatrajući sa aspekta obrazovanja, sve više karakteriše porast potreba za što kvalitetnijim znanjem. To podrazumeva potrebu za efikasnijim modelima obrazovanja koji bi omogućavali da pojedinac racionalnije stiče kvalitetna znanja koje će kasnije tokom života dopunjavati. 
U pogledu kvaliteta obrazovanja postoje mnoge postavke, neke više, neke manje precizne, sve sačinjene u različitim kontekstima, ali postoji mali broj retkih sistematičkih studija o ovom pitanju. U kontekstu obrazovanja, kada mu se pridoda i normativno značenje, termin kvalitet, svakog dana je sve značajniji. Kada govorimo o samom pojmu kvaliteta, on se koristi u značenju stepena izvrsnosti, i to otkrivaju se dva aspekta: jedan je procena vrednosti, a drugi je položaj u odnosu na primenjenu skalu od dobrog ka lošem. Da bi se odredio kvalitet škole, na primer kao „slab“, „osrednji“, ili ,izuzetan“, primenjuje se, manje ili više precizno,određena ideja o vrednosti i identifikuje, opet manje ili više proizvoljno, gde se ta škola nalazi u odnosu na druge škole." Sam pojam kvalitet je višestruk po značenju i često subjektivan. Moguće je identifikovati četiri različite upotrebe te reči: kao atribut ili suština - deskriptivna; kao stepen izvrsnosti ili relativne vrednosti - normativna; kao dobar ili izuzetan - normativna; kao nekvantifikovane karakteristike ili procene - deskriptivna ili normativna“" (Škole i kvalitet, 1998). Znači, kada govorimo o kvalitetu obrazovnog sistema neophodno je analizirati sve segmente obrazovnog procesa.

Gledanje i kontekst kvaliteta obrazovanja može se posmatrati sa različitih sadržajnih pogleda; pedagoškog, didaktičko-metodičkog, sociološkog, kibernetičkog, psihološkog i dr. „Zemlje EU usvojile su 2001. godine strateške ciljeve i komponente obrazovanja za kvalitet, a u svrhu obuke kadrova u toj oblasti““ (Kvalitetno obrazovanje za sve, 2004). Prvi cilj bi se odnosio na unapređivanje kvaliteta i efikasnosti sistema obrazovanja i obuke u EU, u svetlu novih zahteva koje postavlja „društvo znanja“ i izmenjenih modela učenja i nastave, te stvaranje nove koncepcije i strukture kurikuluma, koji bi, svakako, doprineo razvoju kvalitetnijeg obrazovnog sistema. Ostala dva cilja odnosila su se na profesionalni razvoj, socijalnu koherentnost, te otvaranje sistema obrazovanja ka spoljašnjem svetu. ,Zemlje članice Europske unije, i općenito razvijene zemlje, pridaju veliku pažnju obrazovanju kao sredstvu razvoja ljudskog kapitala i jačanje socijalne kohezije, a time i vlastite koherentnosti koja razvojem globalizacijskih postaje sve značajnija“" (Baranović, 2007).

\section{Poimanje kurikuluma i nastavnog plana i programa}

Analizu pojmova „vaspitno-obrazovni program“ i „kurikulum“ započinjemo sagledavanjem istorijskog konteksta u kojem su oni nastali, prateći njihov razvoj do danas. Karakteristično je da se tokom njihovog razvoja prati tendencija njihovog približavanja, pa i izjednačavanja njihovog značenja, kao i period njihovog međusobnog razlikovanja, što je vodilo unapređenju pre svega didaktičke, pa i pedagoške teorije. Izvorno značenje termina kurikulum potiče od latinske reči u kojoj doslovno označava „stazu za trčanje“, sugerišući usmerenost pravca kretanja, utvrđenost cilja. Najkraće rečeno, kurikulum označava „kurs ili plan učenju“ (Akker, 2003). U vaspitno-obrazovni proces ovaj pojam uvodi se sa pojavom preciziranja sadržaja koji se u određenom vremenu i određenim redosledom prenosi učenicima.

U svom osnovnom značenju termin kurikulum se do dana današnjeg održao u anglosaksonskom govornom području. U Evropi krajem 16. veka i početkom 17. veka, u vreme Komenskog i Ratkea ovaj latinski izraz zamenjen je grčkim terminom program, kojim se označava cilj, svrha, zamisao, nacrt, odnosno „raspored po kojem će se raditi“ (Vujaklija, 1988). „U kontekstu školskog sistema pojam program povezuje se sa organizovanjem vaspitno-obrazovnog rada i predstavlja dokument kojim se određuje šta se i zašto uči, a zatim kako i čime. Njime se utvrđuju nastavni ciljevi i zadaci po nastavnim predmetima i razredi- 
ma za jednu vrstu ili tip škole“ (Klemenović, 2009). Taj raspored po kojem će se raditi sa terminom kurikulum dobija naglašenu operativnu funkciju. Termin kurikulum, umesto plan i program, u evropskoj pedagogiji označava sveukupan tok obrazovanja. „Za razliku od tradicionalnih nastavnih planova i programa, u kurikulumu se ciljevi i ishodi obrazovanja, kako na opštem, tako i na pojedinačnim nivoima, definišu tako da imaju operativnu funkciju“ (Školski program, 2003). U Nemačkoj sredinom 20. veka počinje pokret o suštini obrazovanja i nastave čiju osnovu predstavlja kurikularni okret, čime se pojam kurikulum na velika vrata vraća u Evropu. ,Teoretičari ovog pokreta jasno su ukazali na potrebu razlikovanja pojma kurikulum od tradicionalno shvaćenog nastavnog programa (kao propisanih sadržaja učenja). Oni zameraju tradicionalnim programima što se naširoko bave uopštenim formulacijama, a poslednju, vrlo delikatnu i odgovornu, fazu planiranja prepuštaju nastavnicima“" (Klemenović, 2009).

Pobornici pokreta predlažu da se neodređene formulacije zamene jasnim nastavnim zadacima koji se mogu lako razumeti i vode ostvarivanju određenih ciljeva učenja. Redosled tih ciljeva striktno je postavljen, a sadržani su i podaci o načinima za njihovu realizaciju. „Nezaobilazan deo kurikuluma, za razliku od tradicionalnih programa, predstavlja kontrola, odnosno dobijanje povratnih informacija o rezultatu učenja, što je istovremeno i sredstvo za preispitivanje kurikuluma. Tako se od sredine sedamdesetih godina prošlog veka u određenju termina kurikulum sve češće pored tradicionalnih elemenata (institucija, sadržaji, metodički postupci) ističu novi strukturni elementi u vidu ciljeva, sistematizacije i obavezne kontrole“ (Isto, 12). To znači, da bi opsežnije mogli definisati kurikulum od plana i programa. „Kurikulum podrazumijeva opsežno planiranje, ustrojstvo i provjeravanje procesa rada i djelovanja s obzirom na odgovarajuće detaljne ciljeve, sadržajne elemente, te kontrolu (vrjednovanje) postignuća prema globalno postavljenim ciljevima i prema pretpostavkama za odvijanje procesa" (Jurić, 2007). Konstrukt kurikulum je složen i ima multidisciplinarni pristup i značaj.Kurikulum se ne koristi samo u sklopu pedagogije, škole i nastave, već je našao i širu društvenu primenu (Previšić, 2007), što je uslovljeno i samim značenjem ovog pojma (lat.currculum) kojim se obeležava slijed, tijek nekog planiranog događaja.

Devedesetih godina 20. veka, situacija se radikalno menja: i termin i način na koji se poima nastavni program šire se u skoro svim sistemima obrazovanja. „Kao termin sve češće je u upotrebi u Nemačkoj, u Austriji, u nemačkom delu Švajcarske, gde zamenjuje tradicionalni Lehrplan. Sličnu evoluciju vidimo i u Belgiji, pogotovo na flamanskom govornom području zbog blizine Holandije, ali na francuskom govornom području. Čak i u Francuskoj, gde se termin ne pojavljuje u zvaničnim tekstovima, on se sve češće koristi u stručnim krugovima, eksplicitno ili implicitno. U Španiji i Italiji reč kurikulum prevodi se na nacionalni jezik, čime se još jasnije pokazuje volja da se pojam usvoji. Sličan je i slučaj Portugalije“ (Školski program, 2003). Prirodno, upotreba nekog termina ukazuje na interesovanje za fenomen koji taj termin označava. Imamo razloge za uverenje da do širenja termina kurikulum ne bi došlo da nije bilo značajnog interesovanja za samu koncepciju koju taj termin podrazumeva. Uključivanjem društva i partnera u njegovu izradu, prilagođavanjem lokalnom kontekstu, kurikulum rađen po meri svake školske ustanove obezbeđuje iskazivanje socijalnih, ekonomskih i kulturnih osobenosti učenika i regionalnih specifičnosti. Kurikulum se ne može posmatrati iz uskog pedagoškog ugla, rezervisanog samo za stručnjake. „On predstavlja celovito razmišljanje o obrazovanju i otvoren je za sve. To gledište koje privlači pažnju u vreme kada društvo zahteva veću jasnost u donošenju odluka u oblasti obrazovanja i u debatama koje te odluke izazivaju. Zamisao po kojoj svaka škola ima kurikulum po svojoj meri nailazi na veliki odjek kada uniformnost sistema obrazovanja 
sve više izgleda kao puka uobrazilja i kada se nameće potreba za sve većim uvažavanjem sociokulturne raznolikosti učenika i regionalnih specifičnosti“" (Isto, 70). Svuda je prisutna ista težnja: da se izvrši najmudriji izbor znanja i stavova koje obrazovanje treba da razvije kod učenika, kako bi ono odgovorilo na sve snažnije i sve složenije zahteve razvijenog sveta; da se izabrani ciljevi i sadržaji što jasnije i koherentnije formulišu; da se u proces donošenja kurikuluma uključi što širi krug partnera.

U Internacionalnoj enciklopediji obrazovanja (1985) kao osnovne komponente kurikuluma, predstavljaju se: (1) okvirne pretpostavke o onima koji uče i društvu; (2) ciljevi i zadaci; (3) odabrani sadržaji, teme, sekvence ili oblasti; (4) načini prenošenja znanja i metodičke odlike okruženja za učenje i (5) evaluacija.

Ove komponente međusobno su zavisne i povezane, tako da promene u bilo kojoj dimenziji povlače promene u svim drugim dimenzijama. „Zapravo, kurikulum se može označiti kao jedna vrsta tehničkog plana za dostizanje unapred određenih i merljivih ciljeva čije su ključne komponente: teorijske osnove (pedagoške, psihološke i filozofske) na kojima se temelji plan i program uz izbor i redosled sadržaja, ponuda određenih udžbenika i različitih materijala (kurikulumski paket), kao i potrebni uslovi za planiranje, izvođenje i evaluiranje rezultata. U osnovi ovako postavljenog teorijskog modela kurikuluma stoje i sasvim određeni propisi koji uređuju vaspitno-obrazovnu delatnost, ali i pretpostavka o univerzalnosti teorije i njene primenjivosti na sve kontekste (u užem i širem smislu)“ (Klemenović, 2009).

\section{Savremeno shvatanje kurikuluma/programa}

U kontekstu ovog rada pojam savremeni, odnosi se na vremenski period od poslednje dve decenije, znači izlaz iz prošlog veka i prelaz u novi milenijum. U ovom periodu je i redefinisana kriza obrazovanja, pošto je jasno da obrazovanje ne može da odgovori izazovima ubrzanih naučno-tehnoloških, socijalnih i kulturnih promena, kao ni potrebama savremenog društva, ukoliko se programi stalno ne prilagođavaju i menjaju u skladu sa novim vremenom. Pokrenuta su preispitivanja obrazovanja na nacionalnom i međunarodnom nivou (UNESCO, OECD, Savet Evrope) u pravcu istraživanja i redefinisanja ciljeva, zadataka, sadržaja, organizacije i evaluacije nastavnog rada na svim nivoima školovanja. U ovim organizacijama obrazovanje dobija status nezamenjivog dobra u trajnom procesu poboljšanja znanja i umeća, ali i ličnog razvitka. Tako, u savremenim uslovima, kurikulum postaje jedno od najvažnijih sredstava za obezbeđivanje kvalitetnog i ravnopravnog obrazovanja za sve, predstavljajući ne samo odraz datog društva i kulture, nego i projekciju budućeg izgleda tog društva.

$\mathrm{U}$ tom kontekstu krenulo se u reformisanje obrazovnih sistema razvijenih zemalja zapadnog sveta (Evropska Unija, SAD, Kanada, Australija, Novi Zeland), za kojima su nešto kasnili reformski projekti tranzicionih zemalja Centralne i Jugoistočne Evrope. Početkom novog milenijuma ovaj talas zahvatio je i izvesne zemlje Dalekog Istoka (Japan, Koreja, Singapur, Hong Kong) koje, iako kulturno veoma različite nastoje usaglasiti prosperitet sa tekovinama razvijenog sveta.

Predstavljeni savremeni reformski okvir aktualizuje progresivne ideje prema kojima kurikulum / program nije samo dokument i smernica za organizovanje nastavnog rada već se može sagledati kao sveukupno iskustvo koje dete stiče pod rukovodstvom obrazovne institucije. „Od tuda se kurikulum vidi kao realna supstanca vaspitno-obrazovnog procesa 
koja, pored pretpostavljenih principa kao najvažnijih delova kurikuralnih studija, obuhvata i sve one veoma suptilne delove kurikuralnih promena i razvoja koji se događaju u celokupnoj racionalnoj osnovi vaspitno-obrazovnog programa i institucije i svakog pojedinog nastavnika“ (Klemenović, 2009).

Reformski pokret donosi važne promene u shvatanju i važnosti kurikuluma. Proces kreiranja kurikuluma, akcent pomera sa teorijskog modelovanja na plan prakse i konteksta društvena zajednica, škola, razred, porodica. Pomeranje akcenta tumači se kao posledica saznanja da obrazovni ishodi nastaju kao rezultat interakcije između nastavnika i učenika, ali i dece i vaspitno-obrazovne ustanove, te spoljnih elemenata koji utiču na organizaciju ustanove. „Otuda se kao posebno važno pitanje postavlja da li je zvanični program/kurikulum oblikovan tako da omogućava ili koči sretanje svih pomenutih važnih aktivnosti obrazovne ustanove, odnosno koliko računa na stručne radnike u kreiranju konzistentnog vaspitno-obrazovnog koncepta koji je ostvariv u konkretnim uslovima obezbeđujući usklađeno delovanje činilaca skrivenog programa/kurikuluma“ (Isto, 14). Zbog napred navedenih razloga, danas se kurikulum ne donosi strogo određen i završen, već se razvija zajedničkim delovanjem praktičara. Razvoj kurikuluma znači prevođenje vaspitno-obrazovnih zadataka, osnovnih ideja i načela u praksu. Na osnovu proveravanja u praksi, analize i rasprave potvrđuju se, odbacuju ili dograđuju, te se formiraju novi ciljevi i zadaci, tj. dalje se usaglašava kurikulum. „Tako koncipiran program predstavlja proces koji je određen načelima postupanja sa decom (u interakciji), strategijama učenja i poučavanja. Njime se naglasak stavlja na načine, postupke i metode rada sa decom, što ne znači da su programski sadržaji u potpunosti zanemareni“ (Miljak, 1996).

Moglo bi se zaključiti da se danas pojmovi, program vaspitno-obrazovnog rada $\mathrm{i}$ kurikulum gotovo podudaraju, s tim što se za prvu varijantu odlučuju autori koji u prvi plan stavljaju procese decentralizovanja i otvaranje prema specifičnostima života određene zajednice koja zajedno sa decom, roditeljima i celokupnim osobljem obrazovne institucije, uči da preuzme odgovornost za ostvareno. „U drugom slučaju, pažnja je usmerena na odgovornost čitavog društva za ishode obrazovnog procesa od kojeg ne zavisi samo lično napredovanje pojedinca već i prosperitet društva u celini. Više se obraća pažnja na uspostavljanje celovitog sistema u kojem postoji vertikalna i horizontalna povezanost uz pažljivo planiranje saradnje sa lokalnom zajednicom“ (Klemenović, 2009). U prvom slučaju očekuje se participacija što većeg broja učesnika i razvoj namenskih specifičnih programa koji predstavljaju programske intervencije u kojima svi uče i menjaju se. Potencira se rastakanje institucije. U drugom slučaju akcenat je na što većem približavanju projektovanim nivoima razvoja sposobnosti i postignuća u obrazovanju svih učesnika procesa, gde se potencira odgovornost institucije i obrazovna intervencija.

Proces koga određuju načela postupanja sa decom i strategija učenja i poučavanja gradi se i razvija zajedničkom akcijom praktičara. Kurikulum, znači „put koji treba da pređem da bi postigao određene rezultate“" podrazumeva četiri nivoa (slika 1).

Predložena promena sa klasičnih nastavnih planova i programa na kurikulum predstavlja prelazak sa kulture nastavnih planova i programa na kulturu kurikuluma, jer se odlikuje: obrazovanja,

- premeštanjem težišta obrazovnog procesa sa sadržaja na ciljeve i ishode

- orijentacijom na kvalitet ishoda i procesa obrazovanja,

- razvojem sistema evaluacije i samoevaluacije u obrazovanju, 
- zasnivanjem obrazovnih sadržaja na obrazovnim oblastima,

- orijentacijom na učenika i procese učenja,

- podsticajnim, razvojno usmerenim obrazovnim ambijentom.

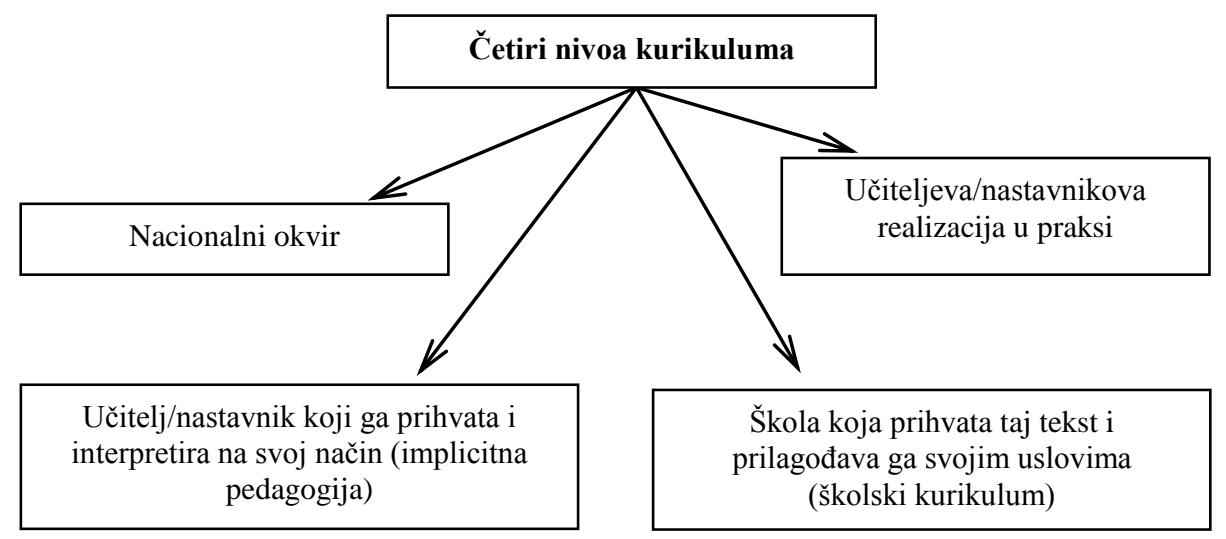

(Izvod iz Školskog razvojnog plana OŠ ,Bratstvo jedinstvo“, Sombor, šk. god.2009/2010)

Slika 1.

Ove promene podrazumevaju: autonomiju i razvoj škola, profesionalnu autonomiju i odgovornost nastavnika koje su moguće u određenim uslovima u kojima škola funkcioniše i stalnu društvenu podršku i brige za efikasnost i kvalitet obrazovnog sistema. „Inovacije u ciljevima obrazovanja uslovljavaju sve dinamičnije promene i u programima škola. Iako je tempo i karakter ovih promena različit, postoji niz tendencija inovacija u ovom domenu koje su zajedničke većini zemalja. One se tiču: uvođenja opšteg, informatičkog, jezičkomatematičkog, multikulturalnog i dr. obrazovanja; davanje veće autonomije školama u donošenju programa i drugo. Posebno je uključen kompleks promena koje uključuju vrednosti (kvalitete) vaspitanja za demokratiju, vaspitanje slobode ličnosti“(Vlahović, 2000). Ipak, najvažniji aspekt promena usmeren je na premeštanje težišta obrazovnih sadržaja na ishode obrazovanja.

\section{Kurikulum u kvalitetnom osnovnom obrazovanju}

Kurikulum je centralna tačka u raspravi o kvalitetu osnovnog obrazovanja. Kada se razmatra kvalitet u odnosu na kurikulum, koji je i sam po karakteru pravi kameleon, onda se nailazi na posebno teške pojmovne probleme. Način definisanja, planiranja, ostvarivanja i evaluacije kurikuluma ima suštinski uticaj na obezbeđivanje kvaliteta u obrazovanju. Osnovni cilj je sagledati najbolji način za sastavljanje kurikuluma, njegovo ostvarivanje i evaluaciju kako bi se na taj način obezbedilo kvalitetno obrazovanje u školi. „, Kritike koje osuđuju kurikulum što je zastareo obuhvataju i one koje žele da vide novi kurikulum ažuriran, ali da je pri svemu tome zadržao svoj tradicionalno liberalan karakter. Ove razlike se neizbežno vezuju sa novim pogledima, često pre, implicitno nego eksplicitno, koji konstituišu kvalitet obrazovanja a time i načine na koje se kurikulum definiše" (Škole i kvalitet, 1998). 
Pojmove koje treba obavezno definisati uz pojam kurikulum su: ishodi obrazovanja, obrazovne oblasti, obrazovni ciklusi, tematske celine i ciljevi obrazovanja, principi obrazovanja. Kurikulum u kvalitetnom osnovnom obrazovanju označava širok spektar različitih shvatanja. U pedagoškoj javnosti terminom kurikulum označavaju se programi, programska dokumenta ili samo delovi školskog programa koji se odnose samo na nastavu. Takođe, pod istim pojmom se podrazumevaju veoma široke obrazovne aktivnosti koje izlaze iz okvira nastave. Ipak dva su generalna pristupa pojmu kurikuluma: jedan je više tradicionalan i kurikulum vidi kao nastavni plan i program, a drugi mnogo otvoreniji i obuhvata uslove u okruženju u kojima se plan i program treba ostvariti. Smatra se da postoje značajne razlike između propisanog (propisani ili preporučeni kurikulum), od onog što nastavnici predaju (predavani kurikulum), naučenog (naučeni kurikulum).

Sve pedagoške rasprave o kurikulumu ne zaobilaze već navode delove i glavne pojmove vezane za njega. „Ishodi obrazovanja - rezultati obrazovne prakse, koji se mogu sistematski pratiti, vrednovati i objektivno utvrditi. Određuju znanja, umeća, stavove i vrednosti koje svaki učenik treba da razvije u okviru određenog nivoa obrazovanja." (Školski program, 2003). Uz pojam ishoda srećemo i pojmove obrazovne oblasti i obrazovne cikluse. „Obrazovne oblasti, srodni nastavni predmeti povezani u jednu oblast kako bi se osiguralo smisleno povezivanje i prožimanje nastavnih sadržaja, vertikalna i horizontalna koherentnost programa, a učenicima obezbedila izgradnja sistema pojmova i znanja. Obrazovni ciklus jednog nivoa obrazovanja koji se razlikuju u funkcionalnom i organizacionom smislu, a zasnovani su na uzrasnim i razvojnim karakteristikama učenika“ (Isto, 64). Nezaobilazni termini po pitanju kurikuluma su i ciljevi obrazovanja i tematske celine. „Tematske celine su srodni sadržaji grupisani u smislenu celinu. Teme mogu biti različite po opštosti i mogu poticati iz različitih domena. Teme se obrađuju prema definisanim ciljevima i ishodima i predstavljaju osnov modela integrisanog učenja. Ciljevi obrazovanja očekivani nameravani ishodi obrazovanja koji predstavljaju osnov za planiranje i realizaciju obrazovnog procesa i definisanje njegovih efekata. Najbitnije u novoj koncepciji kurikuluma je pomeranje težišta obrazovne prakse sa sadržaja na ciljeve i ishode obrazovanja koji su jasno definisani za svaki nivo obrazovanja“" (Isto, 64).

Nova kurikuralna kompetencija, dakle, otvara sistem obrazovanja u suštinskom značenju tog pojma. „Pre svega, principi, ciljevi i ishodi koji trasiraju pravac novog kurikuluma počeli su se definisati u skladu sa razvojnim i obrazovnim potrebama, interesima i interesovanjima učenika, zahtevima savremenog života i društvenim, ekonomskim i kulturnim potrebama“" (Kvalitetno obrazovanje za sve, 2004).

Najbitnija promena u savremenoj koncepciji kurikuluma je pomeranje težišta obrazovanja sa sadržaja na ciljeve i ishode obrazovanja koji su jasno definisani za sve nivoe obrazovanja.

Ova koncepcija kurikuluma omogućava samim nastavnicima da sami biraju adekvatne sadržaje i metode rada u skladu sa celokupnim kontekstom u kojem se odvija proces obrazovanja, što predstavlja mogućnost da kreativnost, sposobnost i stručnost nastavnika / učitelja dođu do izražaja.

Nova strategija kurikuluma, prema novoj koncepciji, obrazovne oblasti postaju polazište za stvaranje kurikuluma, što suštinski stvara mogućnost za uspostavljanje horizontalne i vertikalne povezanosti unutar školskog kurikuluma. Ovo je bitno za poboljšanje kvaliteta učenja i znanja koje učenici stiču i razvijaju, ali i za saradnju i timski rad nastavnika, što do sada nije bila karakteristika naših škola. Nova strategija savremenog kurikuluma omogućava školama veću autonomiju u definisanju kurikuluma po kojem rade. 
„Ključnu promenu predstavlja i nov način regulisanja školskog programa kao i nivo autonomije koji škole imaju u definisanju kurikuluma po kojem rade“(Isto, 40).

Usmerenost na ishode obrazovanja, povezivanje predmeta u oblasti, kao i ostvarivanje prostora za autonomiju i razvoj škola i nastavnika predstavlja takav proces koji sve aktere u obrazovanju podstiče da svoj rad obavljaju efikasnije.

Koncept novog kurikuluma u kvalitetnom osnovnom obrazovanju zahteva osavremenjavanje i prestruktuiranje dosadašnjih planova i programa. Međutim, samo to nije dovoljno. Potrebne su dublje promene koje zadiru u karakter i sistem obrazovanja. Od obrazovanja usmerenog na plan i program prelazi se na obrazovanje usmereno na ishode.

\section{Koncept novog kurikuluma - obrazovanje usmereno na ishode}

Osnovni korak u prelasku kurikuralnog koncepta obrazovanja zasnovanog na ishodima podrazumeva definisanje ishoda obrazovanja za znanja, umenja, stavove i vrednosti koje učenici treba da poseduju nakon završetka određenog nivoa obrazovanja. Ishodi obrazovanja moraju biti definisani tako da omogućavaju objektivno praćenje i evaluaciju funkcionisanja sistema obrazovanja, čime bi se dobio moderan i efikasan mehanizam za osiguranje kvaliteta obrazovanja. „Ishodi (rezultati, ostvareni efekti) obrazovanja određuju znanja, umenja, stavove i vrednosti koje svaki učenik treba da razvije u okviru obaveznog i opšteg srednjeg obrazovanja, kao realizaciju postavljenih ciljeva obrazovanja, radi aktivnog učešća u društvenom životu, uspešnog zadovoljavanja sopstvenih potreba i interesa, razvijanja sopstvene ličnosti i potencijala i doprinosa razvoju društva i kulture“ (Isto, 51). Konkretnije definisan ishod učenja je , precizno napisana izjava o tome šta bi student trebao da zna, razumije ili može da demonstrira na kraju određene jedinice učenja. Iz navedene definicije moguće je izvesti nekoliko bitnih odrednica: ishodi učenja proističu iz unapred definisanih kompetencija (znanja, sposobnosti, vještine); ishodi učenja se definišu na različitim nivoima: obrazovni program, modul, nastavni predmet, nastavni čas; ishodi učenja se uvijek definišu za završetak određenog procesa učenja“ (Branković, 2009). Posebno je važno napomenuti „da unapred definisani ciljevi predstavljaju osnov za koncipiranje, planiranje, organizaciju i realizaciju celokupnog obrazovnog procesa, a utvrđeni ishodi omogućavaju „kontrolu“, evaluaciju, utvrđivanje realnih rezultata (pa i njihove podudarnosti sa nameravanim i očekivanim rezultatima)“"(Školski program, 2003).

Potreba za definisanje ishoda obrazovanja uključuje i potrebu za utvrđenim principima na kojima se zasniva sistem obrazovanja u celini, principi na kojima se zasniva obrazovni proces, kao i opšti ciljevi obrazovanja. Principi, ciljevi i ishodi obrazovanja, međusobno uslovljeni i povezani, proističu jedni iz drugih, i potrebno ih je pojedinačno navesti i objasniti. „Posebno naglašavamo da su i opšti, posebni i pojedinačni ciljevi vaspitanja kategorijalni problem pedagogije. Takvo shvatanje zasnivamo na saznanju da se ciljevi moraju inkorporirati u sam proces vaspitanja i postati njihova konstitutivna komponenta" (Branković, 2009). Iz formulacije pojedinačnih principa, ciljeva i ishoda treba da se jasno vidi logička veza, od načelnih orijentacija do konkretnih rezultata obrazovanja koje želimo da ostvarimo. Opravdana je bojazan da bi sa regulisanjem obrazovanja isključivo kroz ishode, obrazovanjem ovladao duh preteranog pragmatizma. Usmerenost na ishode obrazovanja ne znači zanemarivanje funkcije i značaja sadržaja obrazovanja, uslova u kojima se obrazovni proces odvija, kao i njegovih karakteristika. Radi se o uslovljenim elementima koji prestaju biti cilj sami po sebi već postaju funkcionalni u odnosu na ostvarivanje definisanih ishoda. 
Principe, ciljeve i ishode obrazovanja potrebno je uskladiti sa: razvojnim i obrazovnim potrebama učenika, ali i njihovim interesovanjima. To otvara mogućnost da se ciljevi i ishodi definišu tako, da obrazovanje podstiče i razvija (fizički, intelektualni, emotivni, socijalni, moralni i estetski razvoj) deteta. Osim toga, ciljevi i ishodi treba da se usmere i na određena znanja, umenja, stavove i vrednosti koja su neophodni učenicima s obzirom na izazove svakodnevnog života. Kako bi obrazovanje odgovaralo zahtevima i pravcima konkretizacija ciljeva i ishoda obrazovanja, podrazumeva se:

- definisanje ciljeva i ishoda različitog nivoa opštosti;

- ,produkciju“ ishoda obrazovanja iz definisanih ciljeva - u ovom kontekstu moguće je reći da su ishodi konkretizovani ciljevi.

Time se zahteva sledeće: nije nužno i nije moguće da svaki definisani cilj prati odgovarajući ishod obrazovanja i obrnuto; moguću nepodudarnost u broju definisanih konkretnih ciljeva i ishoda i mogućnost specifikovanja više različitih ishoda iz jednog definisanog cilja obrazovanja.

\section{Koncepcija nove strukture kurikuluma - otvaranje prostora za autonomiju škola i nastavnika}

Koncepcija novog kurikuluma otvara jednu posebnu oblast koncipiranja rada koja podrazumeva otvaranje prostora, za inicijativu i kreativnost nastavnika i škola u programiranju obrazovnog, i školskog rada. Struktura kurikuluma u novoj koncepciji programirana je na dva nivoa. Ukoliko krenemo od toga da pod kurikulumom podrazumevamo sve sadržaje, procese i aktivnosti usmerene na ostvarivanje ciljeva i ishoda obrazovanja, koji su propisani i regulisani, kako na centralnom (nacionalnom), tako i na školskom (lokalnom) nivou. To znači, rad u školi se reguliše na dva nivoa:

\begin{tabular}{|l|l|}
\hline Nacionalni nivo (centralni) & $\begin{array}{l}\text { Školski nivo } \\
\text { (lokalni, nivo pojedine škole) }\end{array}$ \\
\hline Okvirni nacionalni kurikulum & Školski kurikulum \\
\hline dokument: & dokument: \\
\hline Okvir nacionalnog kurikuluma & Školski kurikulum \\
\hline
\end{tabular}

Tabela br. 1. - Šta se reguliše na nacionalnom, a šta na školskom nivou?

Okvirni nacionalni kurikulum osnovnog (bazičnog) kvalitetnog obrazovanja predstavlja osnov za koncipiranje školskog kurikuluma. Okvirni nacionalni kurikulum predstavlja osnovu za sve završne ispite, kao i za sve druge postupke na nacionalnom nivou. Školi i nastavnicima (ali i roditeljima i ostalima koji učestvuju u školskom radu) daje se mogućnost, pravo i odgovornost da, polazeći od propisanog na nacionalnom nivou osmisle, koncipiraju i realizuju obrazovni i školski rad u skladu sa sopstvenim potrebama(potrebama svojih učenika, njihovih roditelja, lokalne sredine) i mogućnostima. „To znači da se konkretne potrebe i mogućnosti moraju prethodno utvrditi, kako bi predstavljale polazište za kreiranje rada, s jedne strane, i da se na nivou škole jasno predstavi u kom pravcu bi se škola mogla razvijati (koje segmente vaspitno-obrazovnog rada bi mogla uspešno realizovati) u periodu od, na primer, 3 do 6 godina“" (Isto, 47). 


\begin{tabular}{|l|l|}
\hline \multicolumn{1}{|c|}{ Okvir nacionalnog kurikuluma } & \multicolumn{1}{c|}{ Školski kurikulum } \\
\hline - opšti ciljevi i ishodi obrazovanja; & $\begin{array}{l}\text { - svi sadržaji, procesi i aktivnosti usmereni na } \\
\text { realizaciju okvirnog nacionalnog kurikuluma; }\end{array}$ \\
\hline $\begin{array}{l}\text { - ciljevi i ishodi obrazovanja za pojedine nivoe i } \\
\text { cikluse obrazovanja; }\end{array}$ & $\begin{array}{l}\text { - predmeti (odnosno teme) koje formira škola, kako } \\
\text { bi zadovoljila specifične obrazovne potrebe i } \\
\text { interese lokalne zajednice; }\end{array}$ \\
\hline $\begin{array}{l}\text { - obrazovne oblasti sa ciljevima i ishodima; } \\
\text { - predmeti (odnosno teme) koji ulaze u sastav } \\
\text { pojedinih obrazovnih oblasti, sa ciljevima i } \\
\text { ishodima specifikovanim za pojedine razrede, } \\
\text { cikluse i nivoe; }\end{array}$ & $\begin{array}{l}\text { - svi sadržaji, procesi i aktivnosti usmereni na } \\
\text { ostvarivanje ciljeva i ishoda za predmete (odnosno } \\
\text { teme) sa liste koju formira škola; }\end{array}$ \\
\hline $\begin{array}{l}\text { - ukupačni predmeti; } \\
\text { temu); }\end{array}$ \\
\hline $\begin{array}{l}\text { - predmeti (odnosno teme) koji su obavezni za } \\
\text { pojedine razrede, cikluse i nivoe obrazovanja; }\end{array}$ & $\begin{array}{l}\text { - ukupan broj časova za svaki razred, koji ne sme } \\
\text { biti manji od minimalno propisanog u okvirnom } \\
\text { nacionalnom kurikulumu. }\end{array}$ \\
\hline $\begin{array}{l}\text { - izborni predmeti (odnosno teme) za pojedine } \\
\text { razrede, cikluse i nivoe obrazovanja; }\end{array}$ & \\
\hline $\begin{array}{l}\text { - minimalni (onaj koji je obavezujući) i maksimalni } \\
\text { (u vidu preporuke kako bi se orijentaciono } \\
\text { odredila gornja granica, ali bez ograničenja škole) } \\
\text { broj časova za svaki ciklus obaveznog i srednjeg } \\
\text { obrazovanja na godišnjem nivou }\end{array}$ & \\
\hline $\begin{array}{l}\text { okvirni broj časova za pojedine obrazovne } \\
\text { oblasti i predmete (odnosno teme). }\end{array}$ & \\
\hline
\end{tabular}

(Preuzeto iz Školski program, 2003, str. 47).

\section{Ciklus obaveznog obrazovanja}

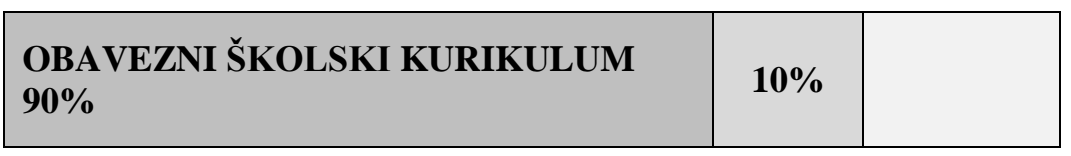

Sl. br. 2. Ciklus kurukuluma

Škola može koristiti „prostor slobode“ koji joj se daje za određene aktivnosti, procese i sadržaje, kao što su:

- na realizaciju fakultativne nastave;

- na realizaciju raznovrsnih vannastavnih i vanškolskih aktivnosti (čime naglašava njihov značaj, a ne zanemaruje njihova uloga u školskom obrazovanju što bi se moglo pogrešno izvesti kao zaključak iz uvida u sadržaj Okvira nacionalnog kurikuluma!);

- na realizaciju programa bazičnih, obaveznih i izbornih predmeta (ili tema) predviđenih ONK, ukoliko se utvrdi da rezultati nisu zadovoljavajući;

- ostalo prema proceni škole.

„Prostor slobode“ se odnosi i na načine realizacije dela programa regulisanog na nacionalnom nivou. 
Šta je to što je obavezujuće tj. jedinstveno za sve škole (učenike, nastavnike), a šta sve škola može da bira i na čemu može da „gradi“ svoju specifičnost (svoju ,ličnu kartu“)?

\begin{tabular}{|c|c|}
\hline $\begin{array}{l}\text { jedinstveno za sve škole } \\
\text { - } \\
\text { ciljevi i ishodi (opšti i specifikovani po } \\
\text { obrazovnim oblastima, obrazovnim } \\
\text { ciklusima, razredima i predmetima); } \\
\text { - minimalni godišnji fond časova za svaki } \\
\text { ciklus u razredu; } \\
\text { - } \text { bazični predmeti (ali bez određenih, } \\
\text { unapred definisanih svih nastavnih } \\
\text { jedinica - tema za pojedine časove); } \\
\text { - ovavezni predmeti u pojedinim ciklusima } \\
\text { i razredima (ali bez određenih, unapred } \\
\text { definisanih nastavnih jedinica - tema za } \\
\text { pojedine časove). }\end{array}$ & $\begin{array}{l}\text { škola bira } \\
\text { - } \text { organizaciju i realizaciju nastavnih sadržaja } \\
\text { kroz predmete ili integrativne teme (ili } \\
\text { kombinovano); } \\
\text { - } \text { konkretne nastavne sadržaje (materiju koja } \\
\text { se obrađuje na jednom nastavnom času) iz } \\
\text { svih predmeta i obrazovnih oblasti - u ONK } \\
\text { ponudiće se samo različite teme od kojih će } \\
\text { se vršiti izbor; } \\
\text { - načine korišćenja otvorenog prostora do } \\
100 \% \text { fonda časova (što će se raditi i kako u } \\
\text { onih } 10,20,30 \% \text { slobodnog prostora); } \\
\text { - didaktičko - metodičke koncepcije } \\
\text { nastavnog rada - strategija i način rada, } \\
\text { nastavnih metoda i vaspitnih postupaka; } \\
\text { - organizacije nastavnog i vaspitno- } \\
\text { obrazovnog rada posebno u drugom i trećem } \\
\text { ciklusu uz mogućnost prevazilaženja } \\
\text { ograničenja razredno-predmetno-časovnog } \\
\text { sistema... }\end{array}$ \\
\hline
\end{tabular}

Tabela br. 2. - Jedinstveno za sve škole/škola sama bira (Preuzeto iz Školski program, 2003, str. 49)

Primer sadržaja jednog dokumenta Školskog kurikuluma koji predstavlja osnovu za rad škole i on sadrži i program razvoja škole u narednom periodu:

- uslovi u kojima škola radi (školski objekti i oprema, materijalno - tehnički uslovi, kadrovski uslovi i td.);

- potreba učenika, nastavnika, roditelja, lokalne sredine i mogućnost škole (na osnovu analiza i istraživanja);

- program rada škole u tekućoj školskoj godini (izvodi se iz Okvira nacionalnog kurikuluma koji je jedinstven i obavezan za sve škole i sve aktivnosti i sadržaji koji čine deo programa razrađenog na nivou škole);

- program razvoja škole u naredne 3 do 6 godina uz naznačene prioritete $\mathrm{i}$ dr.

Predmeti kroz koje se može realizovati nastava u školi su:

- bazični predmeti, koji se obavezno uče na svih nivoima u svim ciklusima obaveznog i opšteg srednjeg obrazovanja i predstavljaju svojevrsnu bazu, osnovu obrazovanja: maternji jezik, srpski jezik (za pripadnike nacionalnih manjina), matematika i strani jezik;

- obavezni predmeti, koji su obavezni za sve učenike na određenim nivoima ili u okviru određenih ciklusa obaveznog i opšteg srednjeg obrazovanja;

- izborni;

- fakultativni

Značajnu ulogu u izradi i planiranju školskog kurikuluma imaju i školski i lokalni timovi učitelja/nastavnika. „Školski tim - aktivi učitelja, nastavnika i profesora svih razreda 
jedne škole. Lokalni tim se formira u saradnji nekoliko škola iste, srodne ili različite vrste, koje ne pripadaju nužno istoj lokalnoj zajednici“" (Isto, 60).

Mogući zadaci školskih i lokalnih timova:

- procena valjanosti sadržaja nastavnih predmeta u odnosu na to u kojoj meri ih učenici zaista usvajaju i kakvog su kvaliteta stečena znanja;

- zajednička izrada kriterijuma za ocenjivanje učenika;

- izrada različitih testova i drugih instrumenata za procenu ishoda, $\mathrm{tj}$. za vrednovanje postignuća učenika.

Timovi učestvuju na pokretanju i razradi različitih projekata škole, kao i razvojnih planova škola.

Novom koncepcijom i savremenom strukturom kurikuluma u kvalitetnom osnovnom obrazovanju nastavnici dobijaju one nadležnosti koje su u prirodi profesionalne uloge koje obavljaju i kojoj pripadaju: postaju kreatori obrazovnog procesa, a ne samo realizatori propisanih i definisanih sadržaja. Nastavnici više nisu samo ,isporučioci“ informacija i činjenica svojim učenicima koje su definisane u Nastavnom planu i programu (a u izradi kojeg nisu učestvovali), već osobe koje u skladu sa svojom stručnošću i psihološko - pedagoškim kompetencijama, a u saradnji sa učenicima, roditeljima, stručnim saradnicima, upravom škole osmišljavaju celokupan obrazovni proces i preuzimaju odgovornost za njegove ishode.

Priprema za izradu školskog kurikuluma i njegova konačna izrada veoma je bitan segment kasnije uspešne realizacije školskog kurikuluma u koji su uključeni navedeni timovi stručnjaka i sami nastavnici/učitelji. Prema Juriću $(2007,278)$ ta priprema sadrži niz sledom pratećih radnji:

1. Snimanje (registriranje okolnosti u školi i procjena njihova utjecaja na budući program, analiza školskih dokumenata) - STANJE

2. Kvalifikacija (određivanje vrste posla i projektiranje mogućih aktivnosti) - ŠTO

3. Kvantifikacija (orijentacijsko utvrđivanje razdoblja i vremena trajanja mogućih aktivnosti) - KOLIKO

4. Orijentacijsko utvrđivanje metoda, postupaka, instrumenata - KAKO

5. Orijentacijsko utvrđivanje subjekata za moguće aktivnosti (nastavnik, stručni suradnik, liječnik i slično) - TKO

Dalja razrada kurikuluma podrazumeva:

6. Odabiranje aktivnosti i poslova za godišnji plan i za perspektivni plan škole

7. Rangiranje utvrđenih aktivnosti prema stupnju važnosti (zajednička procjena nastavnika, stručnih suradnika, ravnatelja)

8. Uvid u iskustva drugih škola i u literaturu

9. Eventualna analiza dosadašnjih vlastitih programa i uvažavanje praćenja i bilježaka

I konačno sledi izrada globalnog kurikuluma:

10. Raspoređivanje i okupljanje aktivnosti prema srodnim područjima

11. Raspoređivanje dijelova kurikuluma $s$ obzirom na logične, tematske $\mathrm{i}$ vremenske okvire

12. Posebno označavanje dijelova kurikuluma koji su izuzetno važni za tu godinu 


\section{Posebno označavanje dijelova kurikuluma koji su veza s proteklim godinama}

14. Posebno označavanje dijelova kurikuluma za koje je potrebna daljnja programska razrada u obliku složenijih projekata odrediti

15. Posebno označavanje dijelova kurikuluma koji se ne mogu vremenski točnije

16. Planiranje vremenskih rezerva za svaki pojedini dio segment i ukupnih vremenskih rezerva.

Sled navedenih koraka veoma je zahtevan i kompleksan proces koji podrazumeva timski rad, koordinaciju i velik broj angažovanih stručnjaka. Precizno konstruisan i isplaniran školski kurikulum put je kvalitetnom obrazovanju konkretne osnovne škole.

\section{Zaključna razmatranja}

Autonomija i razvoj škola, premeštanje težišta obrazovnog procesa sa sadržaja na ciljeve $\mathrm{i}$ ishode obrazovanja, orijentacija na kvalitet, razvoj sistema evaluacije i samoevaluacije u obrazovanju, profesionalna autonomija i odgovornost nastavnika, zasnivanje obrazovnih sadržaja na obrazovnim oblastima, orijentacija na učenika i procese učenja, dinamičan, kvalitetan i podsticajan, razvojno usmeren obrazovni ambijent, stalna društvena podrška i briga za efikasnost i kvalitet obrazovnog sistema, obuhvataju se ovde pojmom kurikuluma.

Dobar školski kurikulum je preduslov nastanka autonomije škole i razvoja njenog identiteta.Način njenog funkcionisanja, koji se, prvenstveno, zasniva na njenom kurikulumu, organizaciji njenog rada, upravljanju nastavnim procesom i njenom interakcijom sa društvenim kontekstom kome pripada, definišu njen identitet i njenu prepoznatljivost. Isto tako, nastava treba da bude usmerena na učenike, a ne na nastavnike, što predstavlja polaznu osnovu za izgradnju identiteta i prepoznatljivosti škole (Bognar i Matijević, 2005).

U skladu sa tim, neophodno je da učitelj da svoj doprinos u prepoznatljivosti škole, na način na koji dolaze do izražaja njegove kompetencije koje je moguće uključiti u nastavu, a koje nisu u direktnoj vezi sa njegovom profesijom (Gllaser, 2005).

Savremeni učitelji treba da nastoje da permanentno usavršavaju svoje sposobnosti i kompetencije. Najčešće su to veštine u upoznavanju i sposobnosti korišćenja računarskih softvera, učenja stranih jezika, ali i nastojanja za razvoj upravljačkih i organizacijskih sposobnosti. Elementi kognitivnih sposobnosti i kognitivne zrelosti u funkciji metodičke kompetentnosti, kao što su: socijalna i emocionalna inteligencija, kognitivna autonomija, otvorenost ka novim iskustvima, vizualizacija metodičkih situacija i rešenja, realističko suđenje, objektivnost i kritičnost mišljenja, kognitivna prijemčivost za inovacije, stvaralačko i divergentno mišljenje, stabilnost vrednosnog sistema, zrelost stavova, bogatstvo i stabilnost interesovanja, autopercepcija (slika o sebi), itd. predstavljaju poželjne oblike psihološke kompetentnosti učitelja/nastavnika (Sakač, 2010).

Domović (2009) razlikuje tri glavna skupa kompetencija učitelja: poznavanje informacionih tehnologija, rad sa ljudima i rad u zajednici i za zajednicu. Prepoznavanje ljudskih resursa u vaspitanju i obrazovanju ključno je za razvijanje kvaliteta nastave i celokupan vaspitno-obrazovni proces. 


\section{Literatura}

Akker, J. (2003): Curriculum percpetives: an introduction. IN: Akker, J., Kuiper W., Hameyer U. (eds). Curriculum landscape and trends. Dordecht: Kluwer academic publishers.

Baranović, B. (2007): Europska iskustva i nacionalni kurikulum za Obavezno obrazovanje u Hrvatskoj. Zagreb, Metodika 18, vol. 8, 294-305.

Branković, D. (2009): Ciljevi, kompetencije i ishodi obrazovanja, Obrazovanje i usavršavanje nastavnika: ciljevi i zadaci vaspitno-obrazovnog rada. Užice: Učiteljski fakultet.

Bognar, L. i Matijević, M. (2005): Didaktika; Zagreb: Školska knjiga.

Domović, V.(2009): Bolonjski proces i promjene u inicijalnom obrazovanju učitelja i nastavnika, U: Vizek Vidović, V. (ur.), Planiranje kurikuluma usmerenog na kompetencije u obrazovanju učitelja i nastavnika: priručnik za visokoškolske nastavnike; http//domus. srce.hr/iucun/

Gllaser,W. (2005): Kvalitetna škola:škola bez prisile. Zagreb: Educa.

Jurić, V. (2007): Kurikulum savremene škole. U: Previšić. V. (ur.): Teorije-metodološki sadržaj strukture. Zagreb: Zavod za pedagogiju Filozofskog fakulteta, Školska knjiga.

Klemenović, J. (2009): Savremeni predškolski programi. Novi Sad: Savez pedagoških društava Vojvodine, Vršac: Visoka škola za obrazovanje vaspitača.

Kvalitetno obrazovanje za sve: izazovi reformr obrazovanja u Srbiji:, Ministrstvo prosvete i sporta R Srbije, Beograd, 2004.

Miljak, A. (1996): Humanistički pristup teoriji i praksi predškolskog odgoja: model izvor. Velika Gorica: Persona.

Previšić,V. (2007). Pedagogija, metodologija kurikuluma. U: Previšić, V. (ur), kuriculum: teorije - metodologija - sadržaj - struktura. Zagreb: Zavod za pedagogiju, Filozofski fakultet u Zagrebu; Školska knjiga, str. 39-115.

Sakač, M. (2010). Kognitivne sposobnosti nastavnika i učenika kao elementi metodičke kompetentnosti, Međunarodna konferencija u Subotici: Savremeni metodički izazovi, 25.X 2010.

Školski program: koncepcija, strategija, implementacija, Komisija za razvoj školskog programa, Ministarstvo prosvete i sporta R Srbije, 2003.

Škole i kvalitet, Zavod za udžbenike i nastavna srestva, Institut za preduzetništvo, Tehnički fakultet Mihajlo Pupin», Zrenjanin, Beograd,1998.

Vlahović, B., Vujsić-Živković, N. (2005): Nastavnik: izazovi profesionalizacije. Beograd: Educa.

Withey, S. (1976).: Quality of Life As An Educational Outcome. New Jersy: Educational Testing Service. 